\title{
Polymerizable Ionic Liquid-derived Non-precious Metal Catalyst Fe-N/C for Oxygen Reduction Reaction
}

\author{
Guogang Xue $e^{1, *}$, Jianjun Tian², Jun Bao ${ }^{3}$, Dan $H u^{3}$ \\ ${ }^{1}$ School of Physics and Electronic Engineering, Kewen College, Jiangsu Normal University, Xuzhou \\ 221116, P.R. China \\ ${ }^{2}$ School of Environmental and Chemical Engineering, Tianjin Polytechnic University, Tianjin 300387, \\ P.R. China \\ ${ }^{3}$ Wuxi Test Institute of Supervision \& Inspection on Product Quality, Wuxi 214101, P.R. China \\ *E-mail: ggxue@jsnu.edu.cn
}

doi: $10.20964 / 2021.01 .71$

Received: 10 October 2020 / Accepted: 15 November 2020 / Published: 30 November 2020

\begin{abstract}
Polymerizable ionic liquid (PIL) of hydrolyzed vinyl imidazolium nitrate $\left([\mathrm{HVim}] \mathrm{NO}_{3}\right)$ was used to prepare the non-precious metal catalyst (NPMC) of Fe-N/C. The material was characterized for catalytic performance toward oxygen reduction reaction (ORR). The onset and half wave potential for ORR is 0.90 and $0.64 \mathrm{~V}_{\mathrm{RHE}}$, respectively. The electrochemical tests show that the $\mathrm{Fe}-\mathrm{N} / \mathrm{C}$ material is a potential NPMC for ORR. Therefore, the PIL is a promising precursor for ORR catalyst free of noble metal.
\end{abstract}

Keywords: Polymerizable ionic liquid; Non-precious metal catalyst; Oxygen reduction reaction; Fuel cell

\section{$\underline{\text { FULL TEXT }}$}

(C) 2021 The Authors. Published by ESG (www.electrochemsci.org). This article is an open access article distributed under the terms and conditions of the Creative Commons Attribution license (http://creativecommons.org/licenses/by/4.0/). 